\title{
豚に対する日本脳炎生ワクチン接種の野外実験
}

\author{
土屋夏 実*・唐木利朗・黑田晃生 \\ 唐牛良明・佐々木修
}

\section{FIELD STUDIES ON IMMUNIZATION OF SWINES USING LIVE ATTENUATED JAPANESE ENCEPHALITIS VACCINE}

\author{
Natsumi TSUCHIYA, Toshiro KARAKI, Akio KURODA, Yoshiaki \\ KAROJI, Osamu SASAKI \\ Department of Microbiology, Public Health Research Institute of \\ Kyoto City, Kyoto, Japan \\ 〔受付 : 2 月 15 日，1971年〕
}

\section{総 括}

Pig-mosquito cycle が日本脳炎ウイルス (JEV) 流 行期に於ける主要な増幅機序であるという生態学的所見 に基づき，1968年から 1970年の 3 年間，京都市内におい て豚に対する日本脳炎生ワクチン接種の野外実験を試み た. 豚の一斉感染期の約 1 力月前（ 6 月中旬 下旬）に 総計13,900頭の豚に日脳生ワクチン( $\mathrm{m}$ 株)を接種し，增 幅抑制効果を検討した.

生ワクチンの効果は主として接種豚舎内採集の吸血コ ガタアカイエカのウイルス感染率, 吸血蚊の HI 抗体に よって判定した。感染率は吸血蚊を 7 日 10日間飼育 した後, JEV 分離を行ない, その分離率から計算した。 吸血蚊 $\mathrm{HI}$ 抗体は採集後直ちに測定し, 豚集団の HI 抗 体保有状況を推定した，その結果つぎのような成績をえ た.

ワクチン接種地域，非接種地域で採集したドライアイ ス誘引蚊の $\mathrm{JEV}$ 保有率は採集地点による著差を認めな かつた.

ワクチン接種豚舎のあるものでは感染開始期が遅延 し, 又一斉感染前の前駆感染が消失するなど, 豚舎にお ける JEV の一般的侵襲パターンと異る形をとつたもの もみられた。

ワクチン接種豚群は流行期前に 20 倍 40 倍の $\mathrm{HI}$ 抗体

* 京都市衛生研究所, 細菌・ウイルス部門

本研究の一部第16回ウイルス学会総会, 第43回, 第 44回日本伝染病学会総会に䋆いて発表した. 1970年の 研究には厚生科学研究補助金が交付された。
が認められるが，流行期に至ると急激な抗体上昇を認め た. ワクチン接種豚舎法非接種豚舎に比し，コガタアカ イエカのウイルス感染率がピーク時で約 $1 / 2$ 以下，全感染 期間を通じての有毒蚊の生産効率が $1 / 4$ 以下であつた。 な お，ワクチン接種による豚の副反応は報告されなかっ た.

以上の野外実験から生ワクチンの有効性が示唆された が，より高い効果を期待するには実験計画，効果判定に 慎重な配慮が必要なことを指摘したい。

\section{序文}

Scherer ら（1959）に指摘されて以来, 多くの研究者 (Konno et al., 1966, Oya, 1967) によって豚が日本脳 炎ウイルスの自然界における最を重要な増幅動物である と考えられている.

Buescher ら（1959）は日本脳炎を予防する方法の 1 つとして豚を免疫することを考慮したが，その効果につ いては強く期待していない.大谷ら（1967）は群馬県下 で小地域の全家畜（豚，家鬼，犬，牛，山羊）を免疫す ることにより, その地域で採集された媒介蚊の JEV 保 有率が対照地域採集蚊の保有率と 異るか否かを検討し た．大谷らの報告によると接種地域採集の媒介蚊からの $\mathrm{JEV}$ 分離は対照より約 2 週間おくれたが，それ以後の 検出率には差がなかつた．最近高橋ら（長崎県報告1969） は壱岐全島の豚に対する日脳生ワクチン接種の実験を行 ないコガタアカイエカからのウイルス分離パターンが非 接種地域に比乙特異的で, 分離頻度も少なかつたと報告 した，大阪府下の実験では接種地区，非接種地区におい 
てドライアイス・ライトトップで採集した未吸血蚊の $\mathrm{JEV}$ 分離率は有意の差を示したと報告されている（上 羽ら，1969)。

これらの野外実験においては調查の資料として接種豚 の抗体の推移と媒介蚊からの JEV の分離が用いられた が，蚊からの JEV 分離を考察する場合，蚊の飛翔分散 を考慮に入れなくてはならぬことは既に大谷が指摘した 通りである。

我々は京都市において1968年から 1970年までの 3 年閒 井上（1964）の作出した生ワクチン（m株）を使用して 広範な肥育豚を免疫する野外実験を行なつた，実験の効 果判定の方法は主として, 豚舎内採集の吸血蚊のウイル 又感染率を用い，同時に吸血蚊による豚集団の HI 抗体 価，ドライアイス誘引蚊の JEV 保有率を併せ 検討し た，その結果，日脳生ワクチン $\mathrm{m}$ 株の豚に対する広範な 接種は JEV の増幅を抑制する一方法であると考えら れ, 又我々が独自に考案した効果判定の方法により，ワ クチン接種の効果判定のみでなく同時に JEV の豚集団 に対する侵襲パターンを考察することが出来たのでその 大要を報告する.

\section{材料と方法}

1) 使用ワクチンと接種方法 :

使用ワクチンの種ウイルスは日脳向井株を HK 細胞 を用いてクローニングし，得られた野生型親ウイルス $\mathrm{m}^{+}$株をマウス胎児線維芽細胞で継代, 更に HK 細胞で の限界希釈法によるクローニングにより得られた弱毒株 である(Inoue, 1964, Kodama et al., 1967).

ワクチンは微生物化学研究所で試験製造された乾燥ワ クチンである. 乾燥ワクチンを生後 $3 \sim 4$ 日の哺乳マウ ス6匹以上を用いて脳内接種法によって検討すると，19 68 年, 1970 年は $10^{5.5} \mathrm{LD}_{50} / 0.02 \mathrm{ml}, 1969$ 年は $10^{5.2} \mathrm{LD}_{50} /$ $0.02 \mathrm{ml}$ の力価を有していた(微研自家検定). 使用時 1 バ イヤル当り $20 \mathrm{ml}$ のゼラチン添加燐酸緩衝液で溶解(ワク チン液 $1 \mathrm{ml}$ 当り約 $10^{6} \mathrm{LD}_{50}$ のウイルス量を有するもの と考えられる)，その $2 \sim 3 \mathrm{ml}$ を豚の頸側部の皮下に 1 回接種した．接種時期は年によって異るが，予想される $\mathrm{JEV}$ の一斎增幅時期より約 1 カ月前を目標として 6 月中 旬〜下旬にかけて接種した。

2) 媒介蚊の採集 :

a) ドライアイスによる誘引；日没直後ドライアイ ス $5 \mathrm{~kg}$ を蚊帳内（最盛期には不要）で昇華させ，これ に誘われて飛来する蚊成虫を捕虫網で採集した.

b) Sweeping; 夜閒豚舎内で捕虫網または吸虫管を 用いて未吸血蚊を採集した。

c) Light-trap による誘引； Light-trap（野沢式
NH- 3 型 BL-管球）を豚舎内一定場所传数個設置し，フ オトスイッチによつて 終夜点燈, 翌朝捕虫部を回収し た.

\section{3）採集の蚊飼育方法 :}

Light-trap 採集の吸血蚊はケージ $(40 \times 40 \times 50 \mathrm{~cm})$ 中 で 7 日 10日間飼育し, 吸血した血液の消化, 蚊体内で の JEV の増殖をまつた後 JEV 分離を行なった，飼育 条件は温度 $28^{\circ} \sim 29^{\circ} \mathrm{C}$, 湿度 $70 \sim 80 \%$ で，14時間照明， $1.5 \%$ 蓔糖液を綿塊に浸して与えた。

4) JEV の分離同定 :

ドライアイスによる誘引, Sweeping 採集の未吸血蚊 は翌日 $4{ }^{\circ} \mathrm{C}$ の低温室で寒冷麻醉下でコガタアカイエカ (Culex tritaeniorhynchus) を選別し，通例100個体を 1 プールとする. Light-trap 採集吸血蚊は7 日 10日 飼育後同様にコガタアカイエカ 50 個体を 1 プールとす る. プール蚊は通常 $-80^{\circ} \mathrm{C}$ で保存され順次 JEV 分離に まわす，各プール蚊は $5.6 \%$ ウシアルブミン液 $5 \%$ を含 む0.01Mリン酸緩衡食塩液 $\mathrm{pH} 7.2$ (PBS) $3 \mathrm{ml}$ (ペニシリ ン500unit $/ \mathrm{ml}$ ，ストレプトマイシン $0.5 \mathrm{mgr} / \mathrm{ml}$ 添加）で 乳錸内で磨砕， $10,000 \mathrm{rpm}, 4^{\circ} \mathrm{C}, 30$ 分遠心，上清を生 後 $3 \sim 4$ 日のDDN 系哺乳マウス 4 匹の脳内に $0.02 \mathrm{ml}$ 接 種した。.マウスは $7 \sim 10$ 日間観察し，発症状況及び発症

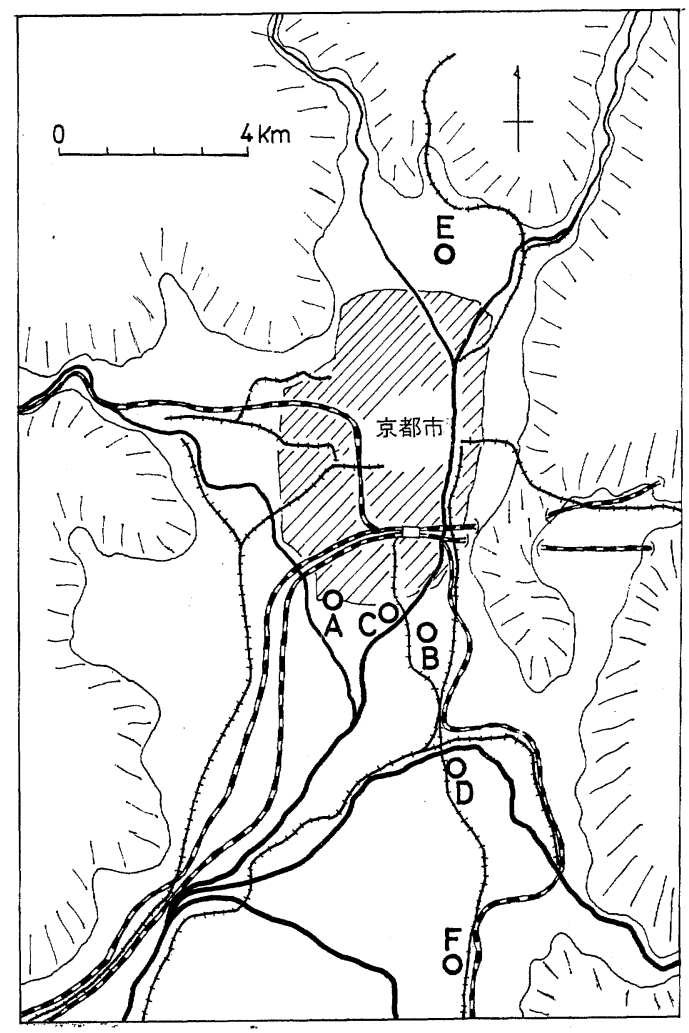

図 1 野外実験調查地点 
表 1 接種・非接種豚舎の吸血蚊感染率（\%)(1968年)

\begin{tabular}{|c|c|c|c|c|c|c|c|c|c|}
\hline $\begin{array}{ll}\text { 採 } & \text { 集 } \\
\text { 個 }\end{array}$ & \multicolumn{3}{|c|}{ A (出橋)豚舎・接種 } & \multicolumn{3}{|c|}{ B (吉祥院) 豚舎・接種 } & \multicolumn{3}{|c|}{$\mathrm{C}$ (向代) 豚舎・非接種 } \\
\hline $\begin{array}{l}\text { 採 集 } \\
\text { 等 }\end{array}$ & $\begin{array}{l}\text { プール } \\
\text { サイズ }\end{array}$ & $\underset{\substack{\text { J } \\
\text { 分離率 }}}{*}$ & $\begin{array}{l}\text { JEV } \\
\text { 感染率 }\end{array}$ & $\begin{array}{l}\text { プール } \\
\text { サイズ }\end{array}$ & $\begin{array}{c}\text { JEV } \\
\text { 分離率 }\end{array}$ & $\begin{array}{l}\text { JEV } \\
\text { 感染率 }\end{array}$ & $\begin{array}{l}\text { プール } \\
\text { サイズ }\end{array}$ & $\begin{array}{c}\mathrm{JEV} \\
\text { 分離率 }\end{array}$ & $\begin{array}{l}\text { JEV } \\
\text { 感染率 }\end{array}$ \\
\hline $7-8$ & 50 & $0 / 2$ & 0.00 & 50 & $0 / 3$ & 0.00 & 50 & $0 / 1$ & 0.00 \\
\hline 9 & 50 & $0 / 7$ & 0.00 & 35 & $0 / 1$ & 0.00 & 50 & $0 / 7$ & 0.00 \\
\hline 11 & 50 & $0 / 12$ & 0.00 & 50 & $0 / 5$ & 0.00 & 50 & $0 / 5$ & 0.00 \\
\hline 12 & 50 & $0 / 9$ & 0.00 & & & & & & \\
\hline 15 & 50 & $0 / 24$ & 0.00 & 50 & $0 / 23$ & 0.00 & 50 & $11 / 24$ & 1.22 \\
\hline 16 & 50 & $0 / 16$ & 0.00 & & & & & & \\
\hline 18 & 50 & $0 / 24$ & 0.00 & 50 & $0 / 11$ & 0.00 & 50 & $0 / 24$ & 0.00 \\
\hline 20 & 50 & $0 / 24$ & 0.00 & 50 & $0 / 24$ & 0.00 & 50 & $0 / 24$ & 0.00 \\
\hline 22 & 50 & $1 / 19$ & 0.11 & 50 & $0 / 12$ & 0.00 & 50 & $1 / 24$ & 0.09 \\
\hline 25 & 50 & $1 / 24$ & 0.09 & 50 & $0 / 14$ & 0.00 & 25 & $9 / 24$ & 1.86 \\
\hline 27. & 50 & 4/ 9 & 1.17 & 50 & $0 / 13$ & 0.00 & 10 & $11 / 24$ & 5.95 \\
\hline 29 & 100 & $4 / 12$ & 0.41 & 50 & $0 / 27$ & 0.00 & 10 & $9 / 24$ & 4.59 \\
\hline 30 & & & & & & & 5 & $4 / 24$ & 3.59 \\
\hline $8-1$ & 50 & $8 / 24$ & 0.81 & 50 & $4 / 24$ & 0.36 & 10 & $6 / 24$ & 2.84 \\
\hline 2 & & & & & & & 10 & $11 / 22$ & 6.70 \\
\hline 3 & 25 & $7 / 24$ & 1.43 & 50 & $6 / 24$ & 0.57 & 10 & $12 / 24$ & 6.70 \\
\hline 5 & 10 & $24 / 48$ & 6.70 & 50 & $6 / 24$ & 0.57 & 10 & $11 / 24$ & 5.95 \\
\hline 8 & 25 & $6 / 22$ & 1.27 & 50 & $5 / 15$ & 0.81 & 25 & $19 / 24$ & 6.08 \\
\hline 12 & 25 & $3 / 24$ & 0.53 & 50 & $9 / 12$ & 2.73 & 25 & $7 / 19$ & 1.82 \\
\hline 15 & 50 & $6 / 24$ & 0.58 & 25 & $9 / 24$ & 1.86 & 50 & $3 / 24$ & 0.27 \\
\hline 19 & 50 & $0 / 23$ & 0.00 & 50 & $0 / 5$ & 0.00 & 25 & $2 / 24$ & 0.34 \\
\hline 30 & 25 & $0 / 11$ & 0.00 & 25 & $0 / 9$ & 0.00 & 25 & $0 / 21$ & 0.00 \\
\hline $9-5$ & 25 & $0 / 4$ & 0.00 & & & & 25 & $0 / 6$ & 0.00 \\
\hline
\end{tabular}

* JEV 陽性プール数/被検プール数

マウス脳の螢光抗体検查によって JEV 陽性と判定し た，必要の場合は発症マウス脳のアセトン・エーテル抽 出抗原を作製し，HA 及び HI によって同定した。

5） ウイルス感染率及び保有率の算出 :

感染率を算出するには通常採集コガタアカイエカの 24 プールを使用し，その陽性プール数 (分離率) から感染 率（\%）を算出した，分離率が $80 \%$ 以上の場合はプール サイズを減少させて再検した，感染率算出式はつぎのよ うに Chiang ら（1962）のものを用いた.

$$
(1-p)^{n}=1-P
$$

但し $\mathrm{p}=$ 感染率 $\mathrm{P}=\mathrm{n}$ 匹プールによる分離率

6) 豚の抗体測定 :

ワクチン接種後豚の耳静脈から採血し, その血清につ き HI 抗体を測定した. 方法は Clarke ら (1958) 大谷 ら（1967）の方法に従いJaGAr 01株抗原の 8 単位と七 ヨコ血球を用いた，又吸血蚊を用いてその吸血宿主の 抗体を推定する方法をとつた，唐木らの報告した方法 （1968，a）に従い吸血蚊を採集翌朝100個体 1 プールと し, 乳鉢で $1 \mathrm{ml}$ の PBS で磨砕, 更に PBS $1 \mathrm{ml}$ を加

え $3,000 \mathrm{rpm}$ 15分遠心，上清を試料として常法に従い $\mathrm{HI}$ 抗体価を測定した. コガタアカイエカの 1 個体当り 吸血量は平均 $2 \mathrm{mg}$ であつたので, アセトン处理後の材 料に䃆酸緩衝液 $1 \mathrm{ml}$ を加えて10倍希釈とし, この吸血 蚊 HI 抗体価によって吸血源である豚集団の抗体価を推 定した．一部の検体遠心上清法 Svehag ら（1964）の方 法に準拠して 2 メルカプトエタノール (2-ME) 処理を 行ない, 2 -ME 感受性を検討した。

\section{成 績}

A）1968年の成績

図 1 亿示す出橋豚舎 (A) 197頭, 吉祥院豚舎 (B) 71頭 海第 1 次 6 月 11 日, 第 2 次 25 日, 日本脳炎生ワクチン 3 $\mathrm{ml}$ を 1 回接種した. 越夏繁殖豚, 2 週間以内出荷予 定豚，授乳中の仔豚は接種を受けなかった。接種豚の月 令は 3 カ月以上のもの $\mathrm{A}$ 豚舎 86 頭 $(43.6 \%), \mathrm{B}$ 豚舎 56 頭 $(78.9 \%)$ であつた， A豚舎から約 $800 \mathrm{~m} ， \mathrm{~B}$ 豚舎か ら約 $2,200 \mathrm{~m}$ 離れた中間地点の向代豚舎 $(\mathrm{C})$ 一飼育頭数 約 800 頭一に扔いてを A, B 豚舎と同様の調査を実施して 


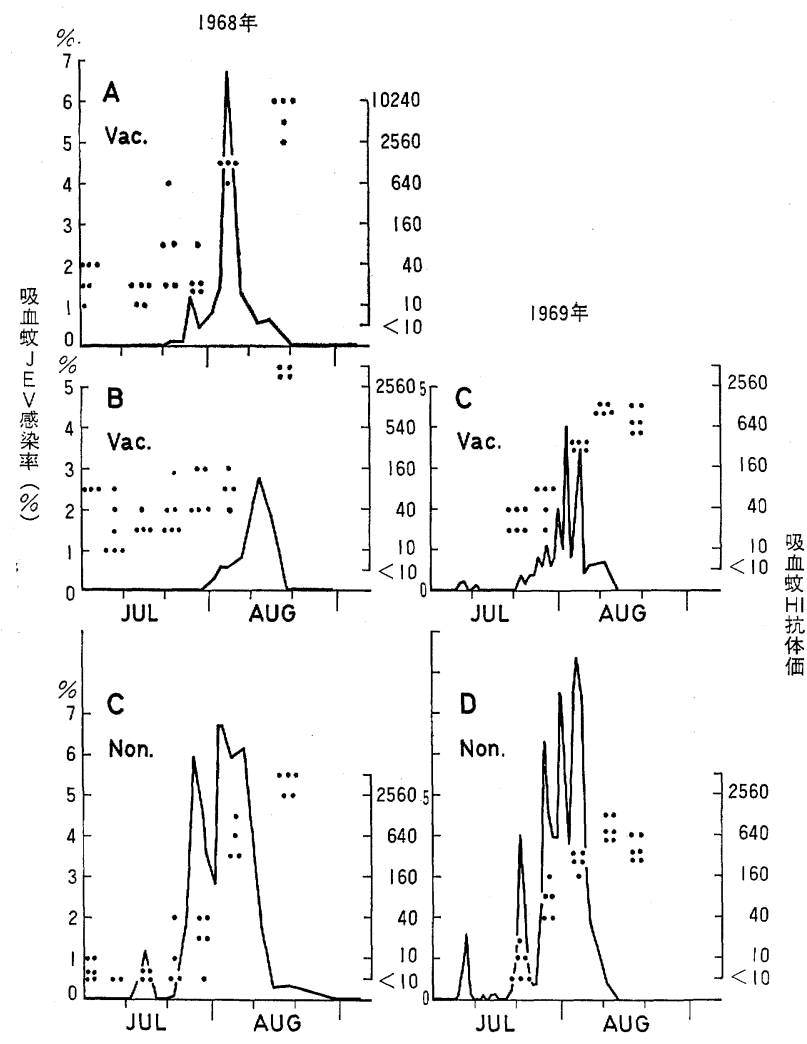

図 2 ワクチン接種・非接種豚舎の吸血蚊感染率と $\mathrm{HI}$ 抗体価 （左1968年，右1969年）

HI 抗体価法・印 1 検体

3 者を比較検討した。

1）吸血蚊のウイルス感染率の推移 :

感染率測定は各豚舎 7 月 1 日から開始し 2 日又は 3 日 おきに測定した。（表 1，図 2)

$\mathrm{A}$ 豚舎注 7 月 22 日始めて $\mathrm{JEV}$ を分離, その後は 8 月 15 日迄連続的に JEV を分離した。 8 月 5 日，感染率は $6.7 \%$ の最高值を示した.

$\mathrm{B}$ 豚舎の最初の $\mathrm{JEV}$ 分離は $\mathrm{A}$ 豚舎より遅れて 8 月 1 日，その後連続的に 8 月 15 日迄 $\mathrm{JEV}$ を分離した. 感染 率は次第に上昇するが，8月12日の最高值においても $2.7 \%$ に止つた.

非接種豚舎 $\mathrm{C}$ の最初の $\mathrm{JEV}$ 分離は $\mathrm{A}, \mathrm{B}$ 豚舎より早 く7月15日であつたが，その後一度 $\mathrm{JEV}$ 分離陰性とな り，7月22日再び JEV を検出した. 以後 8 月 19 日迄連 続的に分離された。感染率では 7 月 27 日 $6.0 \% ， 8$ 月 2 日6.7\%の 2 つのピークが認められた.

3 つの豚舎での感染率を比較すると, ワクチン非接種 C豚舎は媒介蚊の感染が長期にわたり，その期間中の感 染率も高い（最高6.7\%). これに対してワクチン接種豚 舎の媒介蚊の感染期間 は短く, 感染率の最高はA豚舎
$6.7 \% ， \mathrm{~B}$ 豚舎 $2.7 \%$ であつた。 $\mathrm{A}$ 豚舎は 8 月 5 日，1日 だけかなり高い感染率を示したが，その他の感染率は低 い. これは恐らくA豚舎には移行抗体を有する幼若の豚 が多数含まれていたためワクチン接種が無効の例が多か つたのであろう。

各豚舎内採集の吸血蚊の最高感染率の比較のみでな く, 流行期全期間を通じての感染蚊の生産を考察するた めに，毎日の感染率の全感染期間中の総和（以下仮にこ れを感染効率と略称する）を検討した，感染率が毎日測 定されていない場合はその前後の実測值から感染率を推 定して集計した。1968年 は非接種C豚舎の感染効率を 100 とすると接種 $\mathrm{A}$ 豚舎は $41, \mathrm{~B}$ 豚舎は 22 で接種豚舎で の感染蚊の生産は全体として強く抑制されていたことが らかがわれる。

2) 未吸血蚊の JEV 保有率（表 2)：

吸血蚊の中には吸血に飛来する以前に既に感染してい るものがまざつていると考えられるので, 豚舎に飛来す る未吸血蚊の JEV 保有率を検討した.

$\mathrm{A}$ 豚舎は 3 回, 非接種 $\mathrm{C}$ 豚舎は 6 回にわたり未吸血蚊 の $\mathrm{JEV}$ 保有率を測定した， A豚舎の保有率は0.7 1.6 
表 2 豚舎内採集未吸血蚊の JEV 保有率 (\%) (1968年)

\begin{tabular}{|c|c|c|c|c|c|c|}
\hline $\begin{array}{l}\text { 採集 } \\
\text { 個所 }\end{array}$ & \multicolumn{3}{|c|}{$\mathrm{A}$ (出橋) 豚舎 } & \multicolumn{3}{|c|}{ C (向代) 豚舎 } \\
\hline $\begin{array}{l}\text { 採集 } \\
\text { 月旦 }\end{array}$ & $\begin{array}{l}\text { プール } \\
\text { サイズ }\end{array}$ & $\begin{array}{c}\mathrm{JEV} * \\
\text { 分離率 }\end{array}$ & $\begin{array}{c}\mathrm{JEV} \\
\text { 保有率 }\end{array}$ & $\begin{array}{l}\text { プール } \\
\text { サイズ }\end{array}$ & $\begin{array}{c}\text { JEV } \\
\text { 分離率 }\end{array}$ & $\begin{array}{l}\mathrm{JEV} \\
\text { 保有率 }\end{array}$ \\
\hline $7-17$ & & & & 64 & $0 / 2$ & 0.00 \\
\hline 22 & & & & 100 & $1 / 4$ & 0.28 \\
\hline 23 & & & & 100 & $0 / 6$ & 0.00 \\
\hline 25 & & & & 50 & $0 / 1$ & 0.00 \\
\hline $8-2$ & 100 & $5 / 10$ & 0.69 & 100 & $11 / 19$ & 0.86 \\
\hline 8 & 50 & $9 / 16$ & 1.62 & 50 & $8 / 22$ & 0.90 \\
\hline 12 & 50 & $2 / 7$ & 0.67 & 50 & $4 / 11$ & 0.90 \\
\hline
\end{tabular}

* JEV 陽性プール数/被検プール数

表 3 生ワクチン接種豚の HI 抗体価及び $2-\mathrm{ME}$ 処理成績 (1968年)

\begin{tabular}{|c|c|c|c|c|c|c|c|c|}
\hline \multirow{3}{*}{ No. } & \multicolumn{4}{|c|}{ A (出橋) 豚舎 } & \multicolumn{4}{|c|}{$\mathrm{B}$ (吉祥院)豚舎 } \\
\hline & \multirow{2}{*}{ 豚㱓* } & \multirow{2}{*}{$\begin{array}{c}\text { H I } \\
\text { 抗体価 }\end{array}$} & \multicolumn{2}{|c|}{$2-\mathrm{ME}$} & \multirow{2}{*}{ 豚龄 } & \multirow{2}{*}{$\begin{array}{c}\mathrm{H} \text { I } \\
\text { 抗体価 }\end{array}$} & \multicolumn{2}{|c|}{$2-\mathrm{ME}$} \\
\hline & & & 対照 & 处理 & & & 対照 & 処理 \\
\hline 1 & 77日 & 20 & 10 & 5 & 93日 & 20 & & 10 \\
\hline 2 & "I & 40 & 20 & 10 & "I & 20 & 40 & 20 \\
\hline 3 & "I & 20 & - & - & "I & 10 & 5 & 5 \\
\hline 4 & "I & 20 & 10 & 10 & " & 40 & - & - \\
\hline 5 & 11 & 40 & 20 & 20 & "I & 40 & 20 & 20 \\
\hline 6 & 7 月 & 320 & - & - & 4 月 & 320 & 320 & 10 \\
\hline 7 & "I & 10 & 20 & $<5$ & " & 160 & 80 & 20 \\
\hline 8 & "I & 80 & - & - & " & 80 & 40 & 40 \\
\hline 9 & "I & 80 & - & - & "I & 10 & - & - \\
\hline 10 & "I & 40 & - & - & "I & 40 & 40 & 40 \\
\hline
\end{tabular}

* ワクチン接種時の豚噛

(生ワクチン接種22日後採血)

$\%, \mathrm{C}$ 豚舎は最高 8 月 8 日， 12 日の $0.9 \%$ であった。豚 が一斎感染を起している時期でも豚舎内採集の未吸血蚊 の JEV 保有率洛略々 $1 \%$ 程度と考えられる。

3) HI 抗体価の推移（図 2, 表 3):

吸血蚊を用いた $\mathrm{HI}$ 抗体の測定は週 1 回実施した。接 種豚舎 $\mathrm{A}$ の吸血蚊抗体価は接種前いゔれも10倍以下であ るが，接種後の 6 月 14 日以降の検体は 7 月下旬迄 10 倍 80 倍の間に 分布している. A 豚舎の 10 頭をえらんで接 種22日後（7月 3 日）に個別採血した結果は，生後77日 の 5 頭にほ 20 倍 40倍の HI 抗体が認められ，2 -ME処 理を行つた 4 検体 はいづれも $2-\mathrm{ME}$ 耐性で移行抗体と 推定された. 生後 7 カ月の 5 頭の HI 価は 10 倍から 320 倍の間に分布しているが 20 倍の検体は $2 \cdot \mathrm{ME}$ 感受性で あつた．各個体間の差はあるがこれら 5 頭の HI 抗体は 恐らくワクチン接種の応答であろうと考えられる。
表 4 接種 - 数種豚舎の吸血蚊感染率 $(\%)$ (1969年)

\begin{tabular}{|c|c|c|c|c|c|c|}
\hline $\begin{array}{l}\text { 搯集 } \\
\text { 所 }\end{array}$ & \multicolumn{3}{|c|}{$\mathrm{C}$ (向代) 豚舎 - 接種 } & \multicolumn{3}{|c|}{$\mathrm{D}$ (向島)豚舎 - 非接種 } \\
\hline $\begin{array}{l}\text { 採集 } \\
\text { 月日 }\end{array}$ & $\begin{array}{l}\text { プール } \\
\text { サイズ }\end{array}$ & $\begin{array}{c}\text { JEV } \\
\text { 分離摔 }\end{array}$ & $\begin{array}{l}\text { JEV } \\
\text { 感染率 }\end{array}$ & $\begin{array}{l}\text { プール } \\
\text { サイズ }\end{array}$ & $\begin{array}{l}\text { JEV } \\
\text { 分離率 }\end{array}$ & $\begin{array}{l}\text { JEV } \\
\text { 感染率 }\end{array}$ \\
\hline-5 & 50 & $0 / 9$ & 0.00 & 50 & $0 / 12$ & 0.00 \\
\hline 6 & 50 & $0 / 5$ & 0.00 & 50 & $1 / 12$ & 0.17 \\
\hline 7 & 50 & $1 / 15$ & & 50 & $4 / 12$ & 0.8 \\
\hline 8 & 50 & $2 / 22$ & 19 & 2 & $4 / 12$ & 1.6 \\
\hline 9 & 50 & $0 / 8$ & 0.00 & 50 & $1 / 12$ & 0.17 \\
\hline 10 & 50 & $0 / 8$ & .00 & & $0 / 12$ & 0.00 \\
\hline 11 & 50 & $1 / 18$ & 11 & 5 & $0 / 12$ & 0.0 \\
\hline 12 & 50 & $0 / 12$ & 0.00 & 5 & $1 / 12$ & 0.17 \\
\hline 13 & 50 & $0 / 9$ & 0.00 & 50 & $0 / 12$ & 0.00 \\
\hline 14 & 50 & $0 / 6$ & 0.00 & 5 & $1 / 12$ & 0.1 \\
\hline 15 & 50 & $0 / 6$ & 0.00 & & $1 / 12$ & 0.1 \\
\hline 16 & 50 & $0 / 6$ & .00 & 50 & $0 / 12$ & 0.0 \\
\hline 17 & 50 & 6 & 00 & 5 & $0 / 12$ & 0.0 \\
\hline 18 & 50 & $0 / 6$ & 0.00 & 50 & $0 / 8$ & 0.0 \\
\hline 19 & 50 & $0 / 12$ & .00 & 5 & $3 / 24$ & $0.27-2$ \\
\hline 20 & 50 & $0 / 12$ & 0.00 & 5 & $7 / 18$ & 0.9 \\
\hline 21 & 50 & $1 / 12$ & 0.17 & 1 & $8 / 24$ & 3.97 \\
\hline 22 & 50 & $2 / 12$ & 0.36 & 10 & $5 / 24$ & 2.3 \\
\hline 23 & 50 & $1 / 12$ & 17 & & $4 / 12$ & 0.8 \\
\hline 24 & 50 & $2 / 12$ & & & $2 / 12$ & 0.38 \\
\hline 25 & 50 & $2 / 12$ & 0.36 & & $2 / 12$ & 0.3 \\
\hline 26 & 50 & $4 / 12$ & 0.81 & 1 & $5 / 24$ & 2.3 \\
\hline 27 & 50 & $3 / 12$ & 0.57 & 10 & $11 / 23$ & 6.30 \\
\hline 28 & 50 & $5 / 12$ & 1.07 & & $9 / 24$ & 4.5 \\
\hline 29 & 50 & $3 / 12$ & 0.57 & & $8 / 24$ & 3.97 \\
\hline 30 & 50 & $4 / 12$ & 0.81 & 10 & $8 / 24$ & 3.97 \\
\hline 31 & 50 & $7 / 11$ & .00 & & $13 / 24$ & 7.5 \\
\hline $8-1$ & 50 & $5 / 12$ & 1.07 & & & \\
\hline 2 & 10 & $3 / 12$ & 3.95 & 25 & $15 / 24$ & 3.85 \\
\hline 3 & 50 & $4 / 12$ & 0.81 & 10 & $13 / 24$ & 7.5 \\
\hline 4 & & & & 10 & $15 / 24$ & 9.35 \\
\hline 5 & 25 & $7 / 12$ & 3.44 & & $13 / 24$ & 7.5 \\
\hline 6 & 50 & $2 / 12$ & 36 & & $13 / 24$ & 3.0 \\
\hline 7 & 50 & $3 / 15$ & 0.57 & 50 & $11 / 18$ & 1.87 \\
\hline 11 & 5 & $7 / 24$ & & & $1 / 6$ & 0.36 \\
\hline 14 & 50 & $0 / 12$ & 0.00 & 50 & $0 / 6$ & 0.0 \\
\hline
\end{tabular}

$\mathrm{A}$ 豚舎の感染率が最高值を示した 8 月 5 日, $\mathrm{HI}$ 抗体 価は急激に上昇し 640 倍以上を 示し， 8 月下旬， 9 月上 旬採集の検体はすべて 2,560 倍以上である.

$\mathrm{B}$ 豚舎採集の検体注 $\mathrm{A}$ 豚舎より抗体価の上昇が打くれ て 8 月 5 日まで 20 倍 160 倍の間に分布し， 8 月 20 日に はすべて 5,120 倍になった。 B豚舎 7 月 3 日の個別採血 の10頭の HI 抗体価についてみると, 生後93日の 5 頭に は10倍〜40倍の抗体が認められ，2-ME 処理の 4 検体 
表 5 ドライアイス誘引未吸血蚊の JEV 保有率(\%) (1969年)

\begin{tabular}{|c|c|c|c|c|c|c|c|c|c|}
\hline 採 & \multicolumn{3}{|c|}{$\mathrm{C}$ (向代) 地点 } & \multicolumn{3}{|c|}{ D (向島)地点 } & \multicolumn{3}{|c|}{$\mathrm{E}$ (岩倉) 地点 } \\
\hline $\begin{array}{l}\text { 採 集 } \\
\text { 月 }\end{array}$ & $\begin{array}{l}\text { プール } \\
\text { サイズ }\end{array}$ & $\begin{array}{c}\mathrm{JEV} \\
\text { 分離率 }\end{array}$ & $\begin{array}{l}\text { JEV } \\
\text { 保有率 }\end{array}$ & $\begin{array}{l}\text { プール } \\
\text { サイズ }\end{array}$ & $\begin{array}{l}\text { JEV } \\
\text { 分離率 }\end{array}$ & $\begin{array}{c}\mathrm{JEV} \\
\text { 保有率 }\end{array}$ & $\begin{array}{l}\text { プール } \\
\text { サイズ }\end{array}$ & $\begin{array}{c}\mathrm{JEV} \\
\text { 分離率 }\end{array}$ & $\begin{array}{l}\text { JEV } \\
\text { 保有率 }\end{array}$ \\
\hline $7-14$ & 50 & $0 / 8$ & 0.00 & 100 & $0 / 24$ & 0.00 & & & \\
\hline 17 & 100 & $0 / 11$ & 0.00 & 100 & $1 / 12$ & 0.09 & & & \\
\hline 21 & 100 & $0 / 22$ & 0.00 & 100 & $0 / 12$ & 0.00 & 100 & $1 / 24$ & 0.04 \\
\hline 24 & 100 & $4 / 24$ & 0.18 & 100 & $4 / 24$ & 0.20 & 100 & $1 / 20$ & 0.05 \\
\hline 28 & 100 & $6 / 24$ & 0.29 & 100 & $7 / 24$ & 0.34 & 100 & $11 / 24$ & 0.61 \\
\hline 31 & 100 & $12 / 24$ & 0.69 & 100 & $3 / 23$ & 0.14 & 100 & $10 / 24$ & 0.54 \\
\hline $8-5$ & 100 & $7 / 24$ & 0.34 & 100 & $8 / 23$ & 0.43 & 100 & $4 / 12$ & 0.41 \\
\hline 7 & 100 & $5 / 24$ & 0.23 & 100 & $1 / 12$ & 0.09 & 100 & $7 / 24$ & 0.34 \\
\hline 11 & 100 & $10 / 21$ & 0.64 & 100 & $2 / 7$ & 0.34 & 100 & $4 / 24$ & 0.18 \\
\hline 18 & 100 & $0 / 22$ & 0.00 & & & & 100 & $2 / 24$ & 0.09 \\
\hline 20 & & & & 100 & $0 / 24$ & 0.00 & & & \\
\hline 25 & 100 & $0 / 12$ & 0.00 & & & & 100 & $0 / 24$ & 0.00 \\
\hline
\end{tabular}

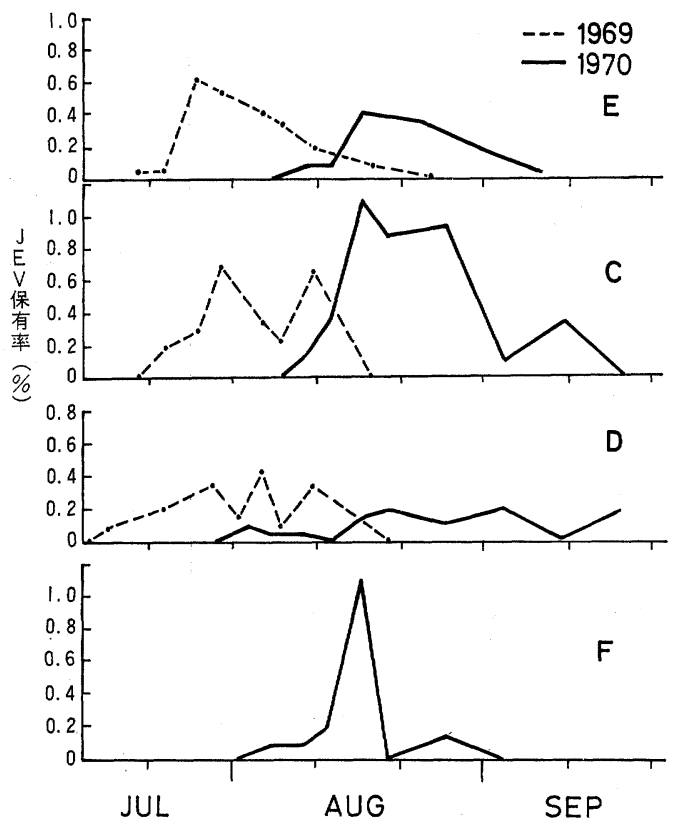

図 3 ドライアイス誘引未吸血蚊 JEV 保有率 の推移

は A豚舍と同様すべて 2 - $\mathrm{ME}$ 耐性であつた. 生後 4 力 月の 5 頭の HI 価は 10 倍から 320 倍の閒にあつたが,

$2-\mathrm{ME}$ 感受性でワクチン接種による抗体と推測される ものと $2-\mathrm{ME}$ 耐性で移行抗体の残存を推定するものと が混在していた。

非接種 $\mathrm{C}$ 豚舎の採集蚊は 7 月 15 日迄10倍又はそれ以下 の HI 抗体価であつたが，7月29日には上昇のきざしを みせ，8月 5 日すべて 320 倍以上となつた。

接種豚舎の 7 月下旬迄の低い $\mathrm{HI}$ 抗体価は吸血蚊抗体 価，個別採血による血清の抗体価両者がほぼ等しく生ワ
クチン接種による抗体応答であろうと考えられる，8月 上旬の接種豚舎の $\mathrm{HI}$ 抗体の急激な上昇はその豚舎の吸 血蚊の感染率の上昇より遅れているので豚集団の自然感 染によるブースター効果の反映と考えられる，B豚舎の $\mathrm{HI}$ 抗体の上昇がA豚舎より遅れているが，吸血蚊感染 率の上昇も B豚舎が遅れており，吸血蚊を用いた抗体測 定が吸血源である宿主の抗体反応を忠実に反映している ことがわかる。

B） 1969年の成績

1969年は1968年から更に接種範囲を拡大した。図 1 の 向代豚舎 $(\mathrm{C})$ を中心に半径約 $1 \mathrm{~km}$ 内の生後 3 力月以上 の肥育豚を接種の対象とした。この地域は鴨川堤防沿い に養豚業者が密集し，市内の豚総数の約 $60 \%$ ，約 6,000 頭の豚が飼育されている，接種前の予備調査で飼育状態 を把握し，6月12日から 27 日迄第 1 次，4,063頭， 7 月 14 日から 17 日迄第 2 次 709 頭，計4,772頭を接種した。 こ の地域に飼育されていた豚は当時14豚舎 5,868 頭であつ たのでその $81.3 \%$ が接種を受けた. 未接種豚 1,096 頭の 中には接種時から 3 週間以内にと畜場に送られる出荷予 定豚878頭が含まれている。

1）吸血蚊のウイルス感染率の推移（表 4, 図 2）： 吸血蚊は接種地域の 中心 $\mathrm{C}$ 豚舎と $\mathrm{C}$ 豚舎 の南方約 4 $\mathrm{km}$ にある向島豚舎 (D) 一飼育頭数約 600 頭一で連日採 集し，その感染率を検討した。

接種 $\mathrm{C}$ 豚舎は 7 月 7 日，8日，11日に吸血蚊から JEV が分離されたが，感染率は甚だ低率であつた. その後 7 月20日迄 JEV は分離されず，7月21日以降は連続的に $\mathrm{JEV}$ が分離された. 感染率は次第に上昇して 8 月 2 日 $4.0 \%, 8$ 月 5 日 $3.4 \%$ のピークを示し，その後减少， 8 月14日には既に分離出来なくなつた。 
非接種D豚舎は 7 月 6 日から 9 日にかけて感染率は小 さなピークを示し，恐らく前駆感染であつたと考えられ る.一度分離は陰性となり，7月19日から連続的に陽性 となつた，感染率の最高值は 8 月 4 日9.4\%である。接 種豚舎，非接種豚舎の最高感染率を比較すると $4.0 \%$, $9.4 \%$ と著差が認められるが，更に感染全期間中の感染 効率を検討すると非接種豚舎の感染効率 100 亿対し接種 豚舎は25で接種豚舎の感染蚊の生産は 1968年のB B豚舎と ほぼ同程度に抑制されていたと推測される。

2) 豚集団の $\mathrm{HI}$ 抗体価（図 2 ）:

非接種D豚舎の 7 月 21 日の吸血蚊抗体注 6 検体中 5 検 体が10倍かそれ以下であるが，接種豚舎 Cでは 20 倍 3 検 体，40倍 3 検体でワクチン接種による $\mathrm{HI}$ 抗体の上昇が 見られた。 7 月28日には C，D両豚舎で $\mathrm{HI}$ 抗体が上昇 傾向をみせ，吸血蚊の感染率のピークである 8 月 4 日に は両豚舎共略々全検体が 320 倍になつた。前年と同様ワ クチン接種豚舎においても豚の一斎感染時期後には $\mathrm{HI}$ 抗体価の上昇が認められた。

3）ドライアイスによる誘引蚊の JEV 保有率(表 5 , 図3):

ドライアイスによる採集は 3 地点，すなわちC豚舎に 近接した鴨川堤防上，D豚舎から約 $300 \mathrm{~m}$ 離れた水田あ ぜ道上，及び $\mathrm{C}$ 豚舎から約 $9 \mathrm{~km}$ 北方の京都市街北端の 岩倉 $(\mathrm{E})$ におふいて実施した。採集は週 2 回行い，コガタ アカイエカから JEV を分離して保有率を算出した。 北 部 $\mathrm{E}$ 地点は 7 月 28 日に最高值 $0.6 \%$ を示し，他の地点は これよりおくれ，C地点が 7 月 31 日 $0.7 \% ， \mathrm{D}$ 地点が 8 月 5 日 $0.4 \%$ の最高值に達した。 $\mathrm{E}$ 地点の保有率 は以後 次第に低下寸るが，C地点は $0.6 \% ， \mathrm{D}$ 地点は $0.3 \%$ の第 2 のピークが 8 月 11 日同時に認められた。南部のC，D 地点の保有率は 2 峰型の曲線をえがきパターンが似てい るが，保有率の高さはワクチン接種地域 C地点の方が非 接種地域 $\mathrm{D}$ 地点より高い.

C) 1970年の成績

1970年は 1969 年より範囲を広げ，京都全市65豚舎の生 後 3 カ月以上の肥育豚すべてを刘象に接種を行なつた. 接種は接種業務を委託された獣医師によつて，6月 1 日 から 6 月 24 日に至る間に実施された。 3 カ月以上の肥育 豚当時の調査では全市で9,799頭で，そのうち8,907頭 が接種を受けた．未接種豚は出荷予定750頭，異常豚142 頭であつた。

1）吸血蚊のウイルス感染率の推移（表 6 , 図 4）：

ワクチン接種豚舎としては前年と同じ向代 (C) 豚舎 を, 非接種豚舎としては京都市南方宇治市大久保の $(\mathrm{F})$ 豚舎をえらび，2 日或いは 3 日毎に感染率を測定した。 接種豚舎C 洌年より約 10 日おくれて 8 月 2 日に始め
表 6 接種・非接種豚舎の吸血蚊感染率 $(\%)$ 1970年

\begin{tabular}{|c|c|c|c|c|c|c|}
\hline $\begin{array}{l}\text { 採集 } \\
\text { 個所 }\end{array}$ & \multicolumn{3}{|c|}{$\mathrm{C}$ (向代) 豚舎 - 接種 } & \multicolumn{3}{|c|}{$\mathrm{F}$ (大久保) 豚舎·非接種 } \\
\hline $\begin{array}{l}\text { 採集 } \\
\text { 月旦 }\end{array}$ & $\begin{array}{l}\text { プール } \\
\text { サイズ }\end{array}$ & $\begin{array}{l}\mathrm{JEV} \\
\text { 分離率 }\end{array}$ & $\underset{\text { 感染率 }}{\mathrm{JEV}}$ & $\begin{array}{l}\text { プール } \\
\text { サイズ }\end{array}$ & $\begin{array}{c}\text { JEV } \\
\text { 分離率 }\end{array}$ & $\begin{array}{l}\text { JEV } \\
\text { 感染率 }\end{array}$ \\
\hline $7-28$ & 50 & $0 / 24$ & 0.00 & 50 & $0 / 24$ & 0.00 \\
\hline 31 & 50 & $0 / 24$ & 0.00 & 50 & $0 / 21$ & 0.00 \\
\hline $8-2$ & 50 & $1 / 24$ & 0.09 & 50 & $5 / 22$ & 0.51 \\
\hline & 50 & $2 / 20$ & 0.21 & 50 & $3 / 23$ & 0.28 \\
\hline 6 & 50 & $4 / 24$ & 0.36 & 50 & $8 / 24$ & 0.81 \\
\hline 7 & 50 & $0 / 24$ & 0.00 & & & \\
\hline 9 & 50 & $14 / 24$ & 1.74 & 50 & $8 / 18$ & 1.17 \\
\hline 11 & 50 & $6 / 24$ & 0.57 & 10 & $18 / 24$ & 12.95 \\
\hline 13 & 10 & $2 / 24$ & 0.87 & 10 & $5 / 13$ & 4.74 \\
\hline 15 & 10 & $15 / 24$ & 9.35 & 10 & $8 / 24$ & 3.97 \\
\hline 17 & 10 & $11 / 24$ & 5.95 & 10 & $8 / 24$ & 3.97 \\
\hline 19 & 10 & $11 / 24$ & 5.95 & 10 & $13 / 23$ & 7.99 \\
\hline 21 & 10 & $7 / 23$ & 3.56 & 10 & $12 / 24$ & 6.70 \\
\hline 23 & 10 & $11 / 24$ & 5.95 & 10 & $4 / 24$ & 1.81 \\
\hline 25 & 10 & $10 / 24$ & 5.25 & 25 & $7 / 18$ & 1.95 \\
\hline 27 & 10 & $6 / 24$ & 2.84 & 25 & $1 / 4$ & 1.14 \\
\hline 29 & 10 & $3 / 24$ & 1.33 & 25 & $0 / 12$ & 0.00 \\
\hline 30 & 50 & $11 / 24$ & 1.22 & & & \\
\hline $9-1$ & 50 & $3 / 24$ & 0.27 & 25 & $1 / 7$ & 0.61 \\
\hline 3 & 50 & $7 / 24$ & 0.68 & 25 & $0 / 12$ & 0.00 \\
\hline 5 & 25 & $1 / 19$ & 0.22 & 25 & $0 / 12$ & 0.00 \\
\hline 6 & 50 & $4 / 12$ & 0.81 & 25 & $0 / 7$ & 0.00 \\
\hline 8 & 25 & $1 / 12$ & 0.35 & 25 & $0 / 2$ & 0.00 \\
\hline 9 & 50 & $0 / 16$ & 0.00 & 25 & $0 / 2$ & 0.00 \\
\hline 11 & 25 & $1 / 12$ & 0.35 & 25 & $0 / 2$ & 0.00 \\
\hline 12 & 10 & $1 / 12$ & 0.87 & & & \\
\hline
\end{tabular}

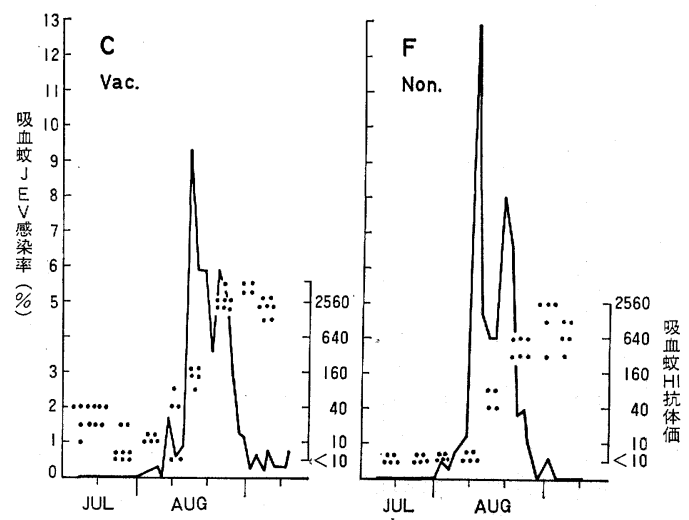

図 4 ワクチン接種・非接種豚舎の吸血蚊感染率 と HI 抗体価(1970年)

て JEV を分離し，その後連続的に JEV を分離した が，分離期間は例年より長く，9月上旬未だ JEV が分 離されていた. 感染率は最高は 8 月 15 日9.4\%であつた。 非接種豚舎 $\mathrm{F}$ は 8 月 2 日から感染率陽性となつたが, 
表 7 ドライアイス梓引未吸血蚊の JEV 保有率(\%)(1970年)

\begin{tabular}{|c|c|c|c|c|c|c|c|c|c|c|c|c|}
\hline \multirow{2}{*}{\begin{tabular}{l|} 
採集 \\
地点 \\
採集 \\
月旦
\end{tabular}} & \multicolumn{3}{|c|}{$\mathrm{C}$ (向代) 地点 } & \multicolumn{3}{|c|}{$\mathrm{D}$ (向島) 地点 } & \multicolumn{3}{|c|}{ E (岩倉)地点 } & \multicolumn{3}{|c|}{ F (大久保) 地点 } \\
\hline & $\begin{array}{l}\text { プール } \\
\text { サイズ }\end{array}$ & $\begin{array}{c}\mathrm{JEV} \\
\text { 分離率 }\end{array}$ & $\begin{array}{c}\text { JEV } \\
\text { 保有率 }\end{array}$ & $\begin{array}{l}\text { プール } \\
\text { サイズ }\end{array}$ & $\begin{array}{l}\mathrm{JEV} \\
\text { 分離率 }\end{array}$ & $\begin{array}{c}\mathrm{JEV} \\
\text { 保有率 }\end{array}$ & $\begin{array}{l}\text { プール } \\
\text { サイズ }\end{array}$ & $\begin{array}{l}\text { JEV } \\
\text { 分離率 }\end{array}$ & $\begin{array}{c}\mathrm{JEV} \\
\text { 保有率 }\end{array}$ & $\begin{array}{l}\text { プール } \\
\text { サイズ }\end{array}$ & $\begin{array}{l}\text { JEV } \\
\text { 分離率 }\end{array}$ & $\begin{array}{l}\text { JEV } \\
\text { 保有率 }\end{array}$ \\
\hline $7-20$ & 100 & $0 / 22$ & 0.00 & 100 & $0 / 24$ & 0.00 & & & & 100 & $0 / 10$ & 0.00 \\
\hline 23 & 50 & $0 / 24$ & 0.00 & 100 & $0 / 24$ & 0.00 & 50 & $0 / 11$ & 0.00 & 100 & $0 / 23$ & 0.00 \\
\hline 27 & 100 & $0 / 24$ & 0.00 & 100 & $0 / 24$ & 0.00 & 100 & $0 / 24$ & 0.00 & 100 & $0 / 22$ & 0.00 \\
\hline 30 & 100 & $0 / 24$ & 0.00 & 100 & $0 / 24$ & 0.00 & 100 & $0 / 24$ & 0.00 & 100 & $0 / 24$ & 0.00 \\
\hline $8-3$ & 100 & $0 / 24$ & 0.00 & 100 & $2 / 24$ & 0.09 & 50 & $0 / 17$ & 0.00 & 100 & $0 / 22$ & 0.00 \\
\hline & & & & 100 & $1 / 24$ & 0.04 & 100 & $0 / 24$ & 0.00 & 100 & $2 / 24$ & 0.09 \\
\hline 7 & 100 & $0 / 24$ & 0.00 & & & & & & & & & \\
\hline 10 & 100 & $3 / 22$ & 0.15 & 100 & $1 / 24$ & 0.04 & 100 & $2 / 24$ & 0.09 & 50 & $1 / 24$ & 0.09 \\
\hline 13 & 100 & $7 / 24$ & 0.34 & 100 & $0 / 24$ & 0.00 & 100 & $2 / 24$ & 0.09 & 100 & $2 / 12$ & 0.18 \\
\hline 17 & 100 & $16 / 24$ & 1.09 & 100 & $3 / 23$ & 0.14 & 100 & $8 / 24$ & 0.41 & 100 & $8 / 12$ & 1.09 \\
\hline 20 & 100 & $14 / 24$ & 0.87 & 100 & $4 / 24$ & 0.18 & & & & 50 & $0 / 15$ & 0.00 \\
\hline 24 & & & & & & & 50 & $4 / 24$ & 0.36 & & & \\
\hline 27 & 100 & $14 / 23$ & 0.93 & 100 & $2 / 21$ & 0.10 & & & & 50 & $1 / 15$ & 0.14 \\
\hline $9-3$ & 100 & $2 / 24$ & 0.09 & 100 & $4 / 24$ & 0.18 & 100 & $4 / 24$ & 0.18 & 50 & $0 / 9$ & 0.00 \\
\hline 7 & & & & & & & 100 & $1 / 22$ & 0.05 & & & \\
\hline 10 & 100 & $7 / 24$ & 0.34 & 100 & $0 / 20$ & 0.00 & & & & 50 & $0 / 24$ & 0.00 \\
\hline 17 & 25 & $0 / 2$ & 0.00 & 50 & $1 / 12$ & 0.17 & & & & & & \\
\hline
\end{tabular}

表 8 生 Vaccine 接種豚舎・非接種豚舎の JEV 感染状況 (1968-1970)

\begin{tabular}{l|c|c|c|c|c}
\hline & \multicolumn{3}{|c|}{1968} & & 1969 \\
\hline
\end{tabular}

ピークはC豚舎より早く 8 月 11 日で，感染率は $13.0 \%$ で あつた. 8 月19日感染率の第 2 のピーク $8.0 \%$ が認めら れ，9月 1 日を最後にC 豚舎より早く JEV は分離され なくなつた. 1970年は前 2 年と異り，接種豚舎の感染率 が非接種豚舎と同程度の高率を示した. 又 $\mathrm{JEV}$ 分離が 遅れて始まり，感染率陽性期間も長期間であつたのが特 徵的である。

2) 豚集団の $\mathrm{HI}$ 抗体価（図 4)：

接種豚舎 $(\mathrm{C})$ 採集の吸血蚊の $\mathrm{HI}$ 抗体は 7 月 15 日, 7 月19日の両回20倍〜40倍程度認められたが，8月10日上
昇し始め，8月17日採集のものはほぼ 160倍，8月24日 に至ると 2,560 倍又はそれ以上となつた。

非接種 $\mathrm{F}$ 豚舎は 8 月 10 日迄すべての検体が 10 倍以下で あつたが，8月17日採集のものはC豚舎と同じく抗体上 昇のきざしが認められ，8月24日に至ると HI 抗体は著 しく上昇して320倍以上となつた. 以づれにしても本年 の $\mathrm{HI}$ 抗体の上昇は吸血蚊のウイルス感染率の上昇と同 じく，例年に比し甚しく遅延した。

3）ドライアイスによる誘引蚊のウイルス保有率（表 7, 図 3): 
前年の採集地点 $\mathrm{C}, \mathrm{D}, \mathrm{E}$ の 3 地点に 南部大久保豚舎 から約 $100 \mathrm{~m}$ 離れた水田辺縁 $\mathrm{F}$ 地点を加え， 4 地点のド ライアイス誘引蚊にっいて保有率を検討した。

北部 $\mathrm{E}$ 地点は 8 月 10 日から JEV が分離され，8月 17 日保有率は $0.4 \%$ のピークに達した。 ピークの時期は昨 年より約 3 週間㧍くれた. 多数の養豚業者の密集する向 代地域 C地点の保有率は 8 月10日から陽性となりピーク は 8 月 17 日で前年より約 20 日間おくれ，ピーク時の保有 率は前年の $0.7 \%$ よりやや高く $1.1 \%$ であった。この地点 の JEV 分離も甚しく長期にわたり 9 月 10 日でも尚 0.3 \%の保有率を示した. C地点の南向島D地点は JEVの 分離が $\mathrm{E}, \mathrm{C}$ 地点より早く 8 月 3 日加始まつた。保有 率の最高值は低く 8 月 20 日の $0.2 \%$ であつたが，ピーク 時期がおくれ，JEV 分離期間が 長びいたことは他地点 と同様である. 非接種地域の $\mathrm{F}$ 地点は 8 月 6 日分離陽性 となって 8 月 17 日 $1.1 \%$ の最高値に達した.

D) 3 年間の小括

3 年間にわたり京都市内の肥育豚に対して種々の規模 においては日脳生ワクチンを接種した結果を表 8 亿要約 した.

吸血蚊感染率によつて特定豚舎の豚感染の状況を見る と，通常多数の豚が Viremia を起して吸血蚊の感染率 が急激に上昇し，同時に或いはややおくれて吸血蚊 HI 抗体も上昇寸る所請一斎感染期と，それょり約 12 日以前 に吸血蚊感染率が 1 日乃至数日間低い陽性を示す前駆感 染を区別することが出来る. ワクチン接種豚舎において はこの前駆感染が認められない例が多かつた，又1968年 の豚舎で見たようにワクチン接種豚舎の豚感染が他豚舎 より遅れる傾向が認められた。

1968年，1969年の接種豚舎における JEV 流行の基本 的特徴は接種豚舎内採集の吸血蚊感染率が非接種豚舎に 比し最高值において低く, 又感染效率を指標にすると, 全感染期間を通じての感染蚊の生産が著しく抑制されて いたことであった.

しかし1970年の接種豚舎の感染率は前 2 年と異り非接 種豚舎より著しく低率になることはなかつた，又接種豚 舎の感染期間も長期にわたつたので接種豚舎の感染蚊の 生産が著しく抑制された所見は認められなかった. 1970 年接種豚舎の感染率が期待通りに低下しなかった原因と して, 流行開始が遅延したため流行期に多数の感受性豚 が接種地域に流入したことが考えられる. 図 5 はワクチ ン接種豚が残存する率を同一豚舎について接種後, 日を 追つて追求したものである. 1969年，1970年を比較する と，1969年は流行開始時接種豚残存率 $290 \%$, 流行末期 でも70\%以上であるのに対し，1970年は流行の遅れによ り流行開始時既に接種豚が約 $50 \%$ しか残つていなかつ
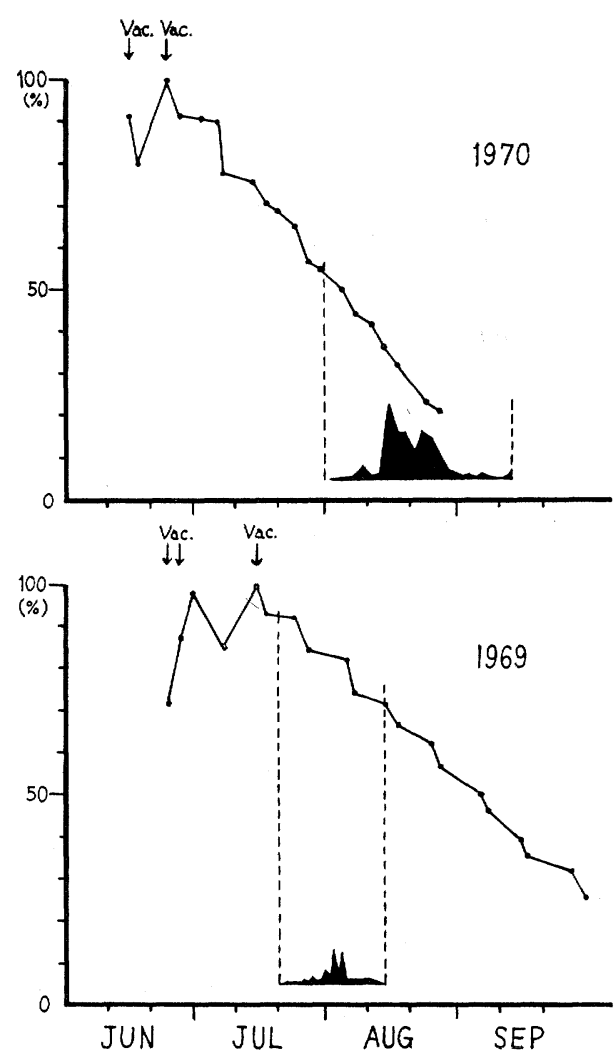

図 5 某豚舎に拈けるワクチン接種豚残存率と 吸血蚊のウイルス分離期閒との関係

た.

1969年，1970年は接種範囲が拡大したので，地域的な 豚免疫がドライアイス誘引による未吸血蚊の JEV 保有 率に影響したかを検討したが，接種地域，非接種地域の 各地点によつて未吸血蚊の JEV 保有率に差がある所見 は得られなかつた。

\section{考察}

井上（1964）によって JEV の弱毒変異株 $\mathrm{m}$ 株が報告 されて以来, $\mathrm{m}$ 株を種ウイルスとする生ワクチンの試作 が行われ，人工哺乳仔豚を使用した室内実験（Kodama et al., 1967)，コガタアカイエカの感染実験 (Takahashi et a.l, 1969) によって, m株生ワクチンの有効性, 安全 性が確認されたが, これを野外に応用した場合, その効 果判定には幾つかの困難な問題がある.

高橋らは壱岐における 野外実験（長崎県報告 1968） で, と場に出荷された接種豚の HI 抗体が生ワクチン接 種によって上昇していることを報告した，我々の実験に おいても接種豚は吸血蚊抗体，個別採血共に HI 抗体陽 性を示し，生ワクチン接種による抗体産生が認められた がその抗体レベルは高くなかつた，日脳流行期に多数の 
有毒蚊が豚を一斉に感染させる時期になると接種豚舎採 集の吸血蚊抗体価は急激に上昇する。室内実験で生ワク チンを接種した豚に強毒株で攻撃を加えると， Viremia は検出出来ないにもかかわらず HI 抗体は 1,280 倍以上 になつたと報告されている（家畜衛生試験場 1969）ので 野外においても接種豚が自然感染によつて Viremia を 起さずに HI 抗体価が上昇することが考えられる。しか し野外実験の接種集団にはワクチン接種時, 移行抗体 を保有しているために接種が有効でない豚が含まれ，そ れらの豚が自然感染によつて高い $\mathrm{HI}$ 抗体を示す可能性 が少くないであろう。我々が行つた1968年の接種豚の個 別採血では，接種時 2 力月， 3 力月の若令豚は HI 抗体 価40倍又流そ以下が 100\%であつて，そのうち2-ME 試験を実施したものはすべて $2-\mathrm{ME}$ 耐性であつた.こ れに対し，4 力月， 7 力月の豚の大部分は HI 抗体価40 倍以上であつたが，4 カ月豚には $2-\mathrm{ME}$ 試験によつて 移行抗体の残存を推測させるものが半数近く存在したの で，生ワクチン接種は 4 カ月以上の豚を対象とすること が望ましいと考えられる。

豚に対するワクチン接種が JEV の Pig-mosquito cycle 中での増幅抑制を期待している以上，その効果の 判定に媒介蚊の JEV 保有率が検討されるのは当然で ある. 大谷ら（1967）は不活化ワクチンを使用して接種 地域と非接種地域の未吸血蚊の JEV 保有率を検討した が，接種地域の保有率が有意に低いとは認められなかつ た. 我々のドライアイスによる誘引未吸血蚊の JEV 保 有率においても接種地域のものが低率であるとは云え なかつた，又 JEV 保有率は我々の成績では $1 \%$ 以下で あるから，地域差を検討するには低すぎるきらいがあ る.

コガタアカイエカの飛翔能力は最大 1 日 $4 \mathrm{~km} \sim 5 \mathrm{~km}$ 程度と推測されるので（前田 1968）， ある地点で採集し た末吸血蚊によつてその地域の JEV 侵淫度を推定する には慎重でなくてはならない. 又採集法が同じでも採集 地点の僅かな相異によつて採集される蚊が質量共に異る ことが多い点も考慮しなくてはならないであるう。

離島といら特殊な条件下で実施された壱岐の実験で は，壱岐各地の未吸血蚊の JEV 分離率が九州本土の分 離率より低く分離パターンも異つていると報告されてい るが（長崎県1968），接種前の壱岐における JEV 侵襲 状況が調查されていないことが問題である. 長崎壱岐 （長崎県1968）大阪府下（上羽ら1969）の野外実験では 未吸血蚊の JEV 保有率の差をワクチンの效果判定の一 方法としているが, 上述の方法論上の問題点が解決され ているとは云えない.

我々が本野外実験で用いた方法は，ドライアイスによ
る誘引，Sweeping 等によって未吸血蚊を採集し，JEV 保有率を検討する従来の方法と異り, 豚舎内の Lighttrap で吸血蚊を採集し，一定期間飼育後その JEV 感染 率を求めて, 各豚舎の豚集団に対する JEV 侵襲状況, 有毒蚊の生産状況を推定したものである. 吸血したコガ タアカイエカの飛翔距離は短いから (唐牛ら1970), 豚舎 内 Light-trap 採集の吸血蚊の吸血源は主としてその豚 舎内の豚であると考えてよい，従つてこの吸血蚊を飼育 乙蚊体内の JEV を增殖せしめて感染率を把握すれば， それは蚊を感染せしめた豚のViremia の存在を鋭敏に とらえていることになる（唐木，1968b）．我々はこの 方法によつて幾つかの豚舎の JEV 侵襲状況を推定した が，生ワクチンを接種した豚舎においては，この方法に より感染蚊の生産の抑制一豚集団のViremia の抑制の 面からワクチンの効果判定に利用することを試みた。

1968年，1969年のワクチン接種豚舎の吸血蚊感染率が 非接種豚舎よりはるかに低いことは，ワクチンの有効性 を表現していると見られよう。接種豚舎の最高感染率は 非接種豚舎の $1 / 2$ 以下であり，全感染期間を通じての感染 効率は非接種豚舎の $20 \%$ 40\%であつた.

1970年の成績は吸血蚊の感染率が接種豚舎, 非接種豚 舎で差がなかつたが，この原因は流行期が予想以上にお くれ，流行開始時期に多数の感受性豚が移入されていた 為と考えられる. 現在の養豚経営形態では間断なく新入 荷豚 (感受性豚) が移入されるから，ある地域の肥育豚 を100\%免疫しても，その後の大荷豚の免疫を絶えず続 行しないと, 流行期に感受性の豚が残こり，生ワクチン 接種豚舎においても有毒蚊の生産は進行することにな る.

ワクチン接種によつて豚における JEV の增幅を抑制 しようとする試みは生態学的理論根拠を有しており, 我 々の野外実験も生ワクチンの安全性，有効性を明らかに したものであると考えているが. この種の野外応用研究 に際しては実施計画, 効果判定方法に慎重な配慮が必要 なことを指摘したい.

\section{謝 辞}

本研究は京都市衛生研究所衛生動物部門との共同研究 である．研究の立案，実施に創意を発揮した同部門前田 理博士に深謝する．又野外実験の実施に当つて援助をい ただいた, 京都市衛生局 (局長松山雄吉博士), 経済局, 京 都府農林部, 微生物化学研究所 (所長传々木文存博士), 京都大学ウイルス研究所井上幸重博士に謝意を表する. 


\section{Summary}

Since 1968 to 1970, field studies in immunization of pigs have been carried out in Kyoto city, to control the transmission of Japanese encephalitis virus (JEV) into mosquito population. One or one and half months before JE epidemic season, a total of 13,900 pigs was vaccinated with the live attenuated Japanese encephalitis vaccine $(\mathrm{m}$ strain) produced by $\mathrm{Dr}$ Inoue. No serious side reaction due to the vaccination was reported.

The result of the vaccination was followed by the determination of the hemagglutination inhibition (HI) antibody level in pigs and by the survey of the infection rate of engorged mosquitoes caught in pig pens. To determine the HI antibody level, blood in visibly engorged mosquitoes was employed. The infection rate was calculated from the JEV isolation rate of engorged mosquitoes which had been incubated for 7-10 days after collection.

HI antibody titers of $1: 20$ or $1: 40$ were observed in the vaccinated pigs although the secondary sharp rises were noted at a time when the wide spread of JEV was observed in nature. The infection rates of the pig pen administered with vaccine were markedly lower than the rates of those not vaccinated; the former was less than $1 / 2$ of the latter at the highest point of the infection rates.

These results suggest that vaccination on pigs seems to be applicable in the field to reduce the density of infected mosquitoes.

\section{文 献}

1) Buescher, E. L. and Scherer, W. F. (1959). Ecologic studies of Japanese encephalitis virus in Japan. IX. Epidemiologic correlation and conclusion. Am. J. Trop. Med. Hyg. 8, 719 -722 .

2) Chiang, C. L. and Reeves, W. C. (1962). Statistical estimation of virus infection rates in mosquito vector populations. Am. J. Hyg. $75,377-391$.

3) Clarke, D. H. and Casals, J. (1958). Techniques for hemagglutination and hemagglutination-inhibition with arthropod-borne viruses. Am. J. Trop. Med. Hyg. 7, 561-573.

4) Inoue, Y. K. (1964). An attenuated mutant of Japanese encephalitis virus. Bull. WHO. $30,181-185$.

5）唐木利朗，前田理(1968 a )。吸血“カ”による 日本脑炎 $\mathrm{HI}$ 抗体測定. 医学の㐫收。65,582586 .
6) 唐木利朗, 土屋夏実, 黒田晃生, 尾崎良克(1986 b). 日本脳炎ウイルスのコガタアカイェカに 上る感染実験とその疫学的応用. ウイルス. 18, 397 (第16回ウイルス学会総会記録).

7）唐牛良明，加藤陸奥雄，石田名香雄，白地良一, 白取剛彦, 山本仁, 今野二郎 (1970)。 日本脳炎 媒介政を中心とした水田地帯の蚊の吸血源の解 析。医学の㐫ゆみ.74，648-650.

8) Kodama, K., Sasaki, N. and Inoue, Y. K. (1967). Studies of live attenuated Japanese encephalitis vaccine in swine. J. Immun. 100 , 194-200.

9) Konno, J., Endo, K., Agatsuma, H. and Ishida, N. (1966). Cyclic outbreak of Japanese encephalitis among pigs and humans. Am. J. Epid. 84, 292-300.

10）前田理 (1968)。 コガタアカイエカの生態一成虫 の移動分散について． 衛生動物．19，137-138 (衛生動物学会第20回大会シンポジウム).

11) Oya, A. (1967). The role of mammals as primary and supplementary host. Jap. J. Med. Sci. Biol., Suppl. 20, 26-30.

12）大谷明, 奥野剛 (1967)：日本脳炎ウイルス。ウ イルス実験学各論. 丸善. 東京.

13) Scherer, W. F., Moyer, J. T., Izumi, T., Gresser, I. and McCown, J. (1959). Ecologic studies of Japanese encephalitis virus in Japan. VI. Swine infection. Am. J. Trop. Med. Hyg., 8, 698-706.

14) Svehag, S-E. and Mandel, B. (1964). The formation and properties of polio virus neutralizing antibody. I. 19s and $7 \mathrm{~s}$ antibody formation; differences in kinetics and antigen dose requirement for induction. J. Exp. Med., 119, 1-19.

15）高橋克巳，松尾礼三，熊正昭，馬場純一，野口 英太郎，田口未春，松本熙，合沢童信，浜里德 雄 (1968)。豚人工免疫による日本脳炎ウイルス 保毒蚊の増幅抑制纪関する研究予報. 熱帯医学. 10, 181-184.

16) Takahashi, M., Yabe, S. and Okada, T. (1969). Effects of various passages on some properties of an attenuated strain of Japanese encephalitis virus with special regard to mosquito infectivity. Jap. J. Med. Sci. Biol. 22, 163-174.

17) 上羽昇, 光田文吉, 前田章子, 大津啓二他 (1969). 日本脑炎の疫学に関する研究 (第 5 報). VIII. ワク チンによる豚の日本脑炎ウイルス堌幅抑制実験. 大阪府公衛研研究報告. 7, 69-74.

18）農林省家畜衛生試験場 (1969)。生ワクチンの感 染防禦効果の研究. 日本脳炎の流行阻止汇関す る特別研究. 科学技術庁研究調整局. 東京.

19）長崎県衛生部，長崎県農林部 (1968)。喜岐日本 脳炎予防特別対策事業報告書. 長崎県衛生部環 境衛生課. 長崎. 